\title{
PENGARUH PELAKSANAAN PROGRAM PENDIDIKAN DAN PELATIHAN TERHADAP PRESTASI KERJA PEGAWAI PADA KANTOR BALAI PENELITIAN TERNAK (BALITNAK) CIAWI-BOGOR
}

\author{
Recika $^{1)}$,Erni Yuningsih ${ }^{2)}$ \\ Program Studi Management Fakultas Ekonomi Universitas Djuanda Bogor \\ Email: recikacika@gmail.com,erni.yuningsih@unida.ac.id \\ Correpondence author : erni.yuningsih@unida.ac.id
}

\begin{abstract}
This research is descrptive and verification which aims to determinee the effectoof the implementation of education and training programs to work performance of emplooyes at Balitnak Ciawi, Bogor. Population in this research were 30 employes who had attended training and education. Data was collected by questionnaires. All variables in this ressearch is valid and reliable, and feasible to use explain the work performance variable. Results of research conducted shows that eduucation and training simultaneously and partially positive and significant impact on the performance of employees Balitnak. Education variable training has an average score of responses at 4.17, which means both categories, and work performance variable have an average score of responses at 4.32, whicch mean excellent category. it is clear that educatiom and trainiing have a close relationship with job performace.
\end{abstract}

Keyword: education and training programs, work performance of employes.

\begin{abstract}
ABSTRAK
Penelitian ini merupakan penelitian deskriptif dan veriifikatif yang bertujuan untuk mengetahui pengaruh pelaksanaan program pendidikan dan pelatihan terhadap prestasi kerja pegawai pada Kantor Balai Penelitian Ternak (Balitnak) Ciawi-Bogor. Populasi dalam penelitian ini adalah 30 pegawai yang pernah mengikuti pendidikan dan pelatihan. Pengumpulan data dilakukan dengan penyebaran kuesioner. Seluruh variabel penelitian inii dinyatakan valid dan reliabel serta layak digunakan untk menjelaskan variabel prestasi kerja. Hasil penelitian menunjukkan bahwa pendidikan dan pelatihan secara simultan dan parsial berpengaruh positif dan signifiikan terhadap prestasi kerja pegawai Balitnak. Variabel program pendidikan memiliki rata-rata skor tanggapan sebesar 4,17 yang berati kategori baik, pelatihan 4,34 sangat baiik dan prestasi kerja 4,32 sangat baik. Hal ini menjelaskan bahwa pendidikan dan pelatihan memiliki hubungan erat dengan prestsi kerja.
\end{abstract}

Kata kunci: Program pendidikan dan pelatihan, prestasi kerja.

Pengaruh Pelaksanaan Pendidikan Dan Pelatihan Terhadap Prestasi Kerja .... | 34 


\section{PENDAHULUAN}

Sumber daya manusia memainkan peran yang sangat penting bagi keberlangsungan hidup dan perkembangan organisasi. Oleh karena itu, pegawai diharapkan selalu mengasah pengetahuan, keterampilan serta kemampuan agar lebih baik sesuai dengan tuntutan zaman.

Pendidikan dan pelatihan adalah kunci dalam manajemen yang memainkan peran penting dan strategis terhadap prestasi kerja (Sutrisno, 2011:151). Kantor Balitnak merupakan suatu instansi pemerintahan yang terus berupaya mengemangkan SDM dan produktivitas pegawainya.

Bedasarkan data awal terdapat indikasi turunnya prestasi kerja pegawai pada Kantor Balitnak Ciawi-Bogor. Hal ini ditunjukkan oleh pencapaian kinerja instansi yang masih dibawah target yang ditentukan. Pengembangbiakan hewan ternak pada tahun 2015 tidak mencapai target yang ditentukan sebanyak 2000 ekor, karena hanya mencapai $85 \%$ yaitu sebanyak 1700 ekor.

Di samping itu, dalam melaksanakan tugas-tugasnya masih terdapat pegawai yang belum mencapai Sasaran Kerja Pegawai (SKP) pada tahun 2015 yang ditentukan sebesar 85,63\% dari target sebesar $87,50 \%$. Selain itu, belum tercapainya pegawai dapat dilihat dari hasil pekerjaan. Hal ini terlihatdari kurangnya tanggung jawab pegawai, misalnya ketepatan waktu dalam menyelesaikan tugas, kesiap-siagaan di tempat kerja dalam segala keadaan dan pengutamaan kepentingan dinas diatas kepentingan pribadi.

Program Pendidikan pada Kantor Balitnak dilakukan dengan cara memberikan rekomendasi pada pegawai yang berpendidikan $\mathrm{S} 1$ kemudian melanjutkan kependidikan S2 atau pendidikan S2 melanjutkan S3 dengan biiaya yang ditanggung oleh perusahaan selama 2 tahun. Apabila dalam 2 tahun pegawai tidak mampu menyelesaiikan pendidikan, maka biaya selanjutnya ditanggung oleh pegawai itu sendiri.

Sedangkan program pelatihan pada Balitnak dilakukan berdasarkan kemampuan pegawai dalam bekerja yang masih belum optimal, seperti pelatihan bahasa Inggris, teknik kehumasan bagi pegawai humas, penulisan jurnal Internasional dan teknik formulasi ransum Ruminansia dan non Ruminansia.

Banyak faktor yang mempengaruhi prestasi kerja, antara lain kepemimpinan, lingkungan kerja, disiplin kerja, motivasi kerja, pendidikan dan pelatihan (Sutrisno, 2011).

Berdasarkan uraian tersebut memilih judul "Pengaruh Pelaksanaan Program Pendidikan Dan Pelatihan Terhadap Prestasi Kerja Pegawai Pada Kantor Balai Penelitian Ternak (Balitnak) Ciawi Bogor".

\section{MATERI DAN METODE}

Menurut Uhbiyati (2007), pendidikan pada hakekatnya merupakan suatu kegiatan yang secara sadar dan disengaja, serta penuh tanggungjawab yang dilakukan oleh orang dewasa kepada anak sehingga timbul interaksi dari keduanya agar agar anak mencapai kedewasaan yang dicita-citakan dan berlangsung terus menerus.

Adapun tujuan pendidikan menurut Notoatmodjo (2003) yaitu, menanamkan pengetahuan, mengubah sikap dan persepsi, menanamkan tingkah laku.

Menurut Husnan (2007:80), indikator pendidikan adalah pemahaman tugas, wewenang dan tanggungjawab, menerapkan pengetahuan, pengambilan keputusan, mengatasi kesulitan pekerjaan.

Pegawai merupakan kekayaan organisasi yang paling beharga, dengan posisi yang dimilikinya dapat terus dilatih 
dan dikembangkan, sehingga dpat memberikan kontribusi dan prestasi yang optimal untuk mencapai tujuan organisasi. Seorangpegawai yang ditugaskan untuk mengerjakan suatu pekerjaan tertentu sudah mempunyai pendidikan, dan untuk meningkatkan agar mampu mengerjakan tugasnya dengan baik masih dperlukan pendidikan danpelatihan khusus.

Menurut Notoatmojo (2001), pelatihan adalah setiap usaha untuk memperbaiki performance pekerja yang sedang menjadi tanggungjawabnya, atau yang ada kaitannya dengan pekerjaanya. Nitisemito (2006) menyatakan bahwa tujuan dari pelatihan adalah pekerjaan diharapkan lebih cepat dan baik, penggunaan bahan baku yang hemat, penggunaan pelatan dan mesin diharapkan lebih tahan lama, angka kecelakaan dharapkan menjadi lebih kecil, tanggungjawab lebih besar, biaya produksi rendah, kelangsungan hidup perusahaan menjadi lebih terjamin.

Heidirachman (2007), menyatakan bahwa indikator pelatihan sebagai berikut: materi pelatihan dapat dimengerti, pelatihan sesuai tugas, pelatihan dapat meningkatkan keterampilan, hasil penelitian diterapkan di tempat kerja, pelatihan meningkatkan prestasi kerja.

Mangkunegara (2003), menyatakan bahwa tujuan pokok dari setiap pendidikan dan pelatihan adlah untuk merubah kemampuan penampilan seseorang didalam melaksanakan pekerjaanya, sedangkan kebijaksanaan umum daripada suatu pelatihan adalah agar pegawai dapat melaksaan pekerjaanya dengan efisien dan efektif.

Menurut Hasibuan (2002:94), prestasi kerja adalah suatu hasil kerjs yang dicapai seseorang dalam melaksanaakan tugas yang dibebankan kepadanya yang didsarkan atas kecapan, pengalaman, dan kesungguhan serta waktu. Setiap instasi berusaha untuk meningkatkan prestasi pegawai agar tujuan instansi yang bersangkutan dapat berjalan baik.

Usaha dalam meningkatkan prestasi kerja terdiri dari berbagai faktor, salah satunya adalah pendidikan dan pelatihan. Program pendidikan dan pelatihan merupakan faktor penting untuk pengembangan sdm.

Pendidikan danpelatihan diberikan untuk pegawai baru maupun lama. Karena melalui pendidikan dan pelatihan, pegawai baru diharapkan akan dapat melakukan pekerjaanya dengan baik dan melaksanakan kewajibanya dengan instansi.

Pada akhirnya para pegawai bekerja dan memiliki prestasi kerja yang baik. Secara skematis proses pendidikan dan pelatihan diuraikan diatas dapat digambarkan sebagai berikut:

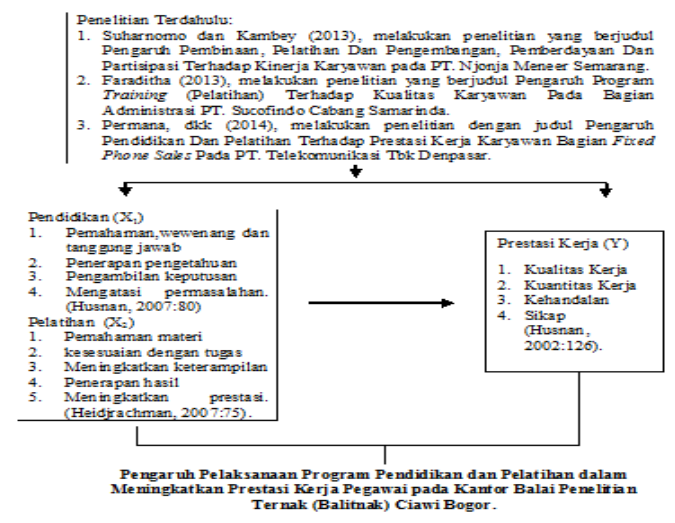

Gambar 1. Kerangka Pemikiran

Berdasarkan kerangka pemikiran tersebut, maka peneliti menyusun hipotesis sebagai berikut:

1. Pendidikan dan pelatihan secara simultan berpengaruh positif dan signifikan terhadap prestasi kerja pegawai Balitnak Ciawi-Bogor.

2. Pendidikan berpengaruh positif dan signifikan terhadap prestasi kerja pegawai di Kantor Balitnak. 
3. Pelatihan berpengaruh positif dan signifikan terhadap prestasi kerja pegawai Balitnak.

\section{HASIL DAN PEMBAHASAN}

\section{Karakteristik Pegawai}

Secara deskriptif diketahui pegawai yang menjadi responden dalam peneliti-an ini didominasi oleh laki-laki (67 persen). Dari sisi usia, mayoritas responden berada dalam rentang usia 41 - 50 tahun (37 persen). Sementara itu, dari sisi pendidikan, mayoritas responden penelitian mengenyam pendidikan S1 (40 persen).

Tabel 1. Karakteristik Pegawai

\begin{tabular}{clll}
\hline No & $\begin{array}{l}\text { Kriteria } \\
\text { Pegawai }\end{array}$ & Karakteristik & $\begin{array}{l}\text { Jumlah } \\
\text { (orang) }\end{array}$ \\
\hline 1 & Jenis & Laki-laki & $20(67 \%)$ \\
& Kelamin & 41-50 Tahun & $11(37 \%)$ \\
2 & Usia & S1 & $12(40 \%)$ \\
3 & Pendidikan & \\
\hline
\end{tabular}

Dari tabel 2 di bawah dapat diketahui bahwa penilaian pegawai untuk variabel pendidikan sebesar 4,17 atau kategori baik. Penerapan pengetahuan yang telah didapatkan dari program pendidikan ke dalam pekerjaan memilki skor tertinggi yaitu 4,26 dan terendah 4,13 mengenai program pendidikan membantu dalam mengatasi kesulitan yang berhubungan dengan pekerjaan.

Berkaitan dengan hal di atas, persepsi yang masih rendah berkaitan dengan program pendidikan membantu dalam mengatasi kesulitan-kesulitan yang berhubungan dengan pekerjaan memungkinkan instansi harus terus menerus mengembangkan materi-materi pendidikan yang berkaitan dengan teknis pelaksaaan pekerjaan sehingga mampu mengatasi kesulitan-kesulitan pegawai mengatasi permasalahan dalam pekerjaannya.
Tabel 2. Rekapitulasi Tanggapan

Pegawai Untuk Variabel Pendidikan

\begin{tabular}{llcr} 
No & Pernyataan & $\begin{array}{c}\text { Penilaian } \\
\text { Pegawai }\end{array}$ & Keterangan \\
\hline 1 & $\begin{array}{l}\text { Pemahaman } \\
\text { atas pekerjaan }\end{array}$ & 4.16 & Baik \\
2 & $\begin{array}{l}\text { Penerapan } \\
\text { pengetahuan } \\
\text { kedalam } \\
\text { pekerjaan }\end{array}$ & 4.26 & Sangat Baik \\
3 & $\begin{array}{l}\text { Program } \\
\text { pendidikan } \\
\text { sangat } \\
\text { membantu }\end{array}$ & 4.16 & Baik \\
4 & $\begin{array}{l}\text { Program } \\
\text { pendidikan } \\
\text { membantu } \\
\text { mengatasi } \\
\text { kesulitan } \\
\text { dalam } \\
\text { pekerjaan }\end{array}$ & 4.13 & Baik \\
\hline & & \\
\hline Total & 16.71 & \\
\hline Rata-rata & 4.17 & Baik \\
\hline
\end{tabular}

Berdasarkan tabel 3 soal rekapitulasi tanggapan responden atas variabel pelatihan diketahui bahwa rata-rata penilaian pegawai untuk variabel pelatihan diperoleh sebesar 4,34 dengan interpretasi sangat setuju, artinya pelatihan yang dilaksanakan instansi sangat mendukung terhadap upaya-upaya pencapaian pres-tasi kerja.

Mengajarkan kepada rekan tentang pengetahuan atau metode baru yang diperoleh dari mengikuti pelatihan memiliki skor tertinggi sebesar 4,50 dan terendah mengenai pelatihan mampu meningkatkan prestasi kerja sebesar 4,26.

Pelaksanaan program pelatihan ini tentunya bukan hanya dilakukan kepada pegawai baru saja tetapi juga untuk pegawai lama, tujuanya adalah meningkatkan prestasi kerja pegawai. Hal ini didukung oleh penelitian Eli Yulianti (2015) dengan judul pengaruh pelatihan terhadap kinerja karyawan Grand Fatma Hotel di Tenggarong Kutai Kartanegara. 
Tabel 3. Rekapitulasi Tanggapan Pegawai Untuk Variabel Pelatihan

\begin{tabular}{llcr}
\hline No & Pernyataan & $\begin{array}{c}\text { Penilaian } \\
\text { Pegawai }\end{array}$ & Keterangan \\
\hline 1 & $\begin{array}{l}\text { Pemahaman } \\
\text { atas pekerjaan }\end{array}$ & 4.16 & Baik \\
2 & $\begin{array}{l}\text { Penerapan } \\
\text { pengetahuan } \\
\text { kedalam } \\
\text { pekerjaan }\end{array}$ & 4.26 & Sangat Baik \\
3 & $\begin{array}{l}\text { Program } \\
\text { pendidikan }\end{array}$ & 4.16 & Baik \\
& $\begin{array}{l}\text { sangat } \\
\text { membantu } \\
\text { Program } \\
\text { pendidikan } \\
\text { membantu } \\
\text { mengatasi } \\
\text { kesulitan } \\
\text { dalam } \\
\text { pekerjaan }\end{array}$ & 4.13 & Baik \\
\hline Total & & \\
\hline Rata-rata & 4.17 & \\
\hline
\end{tabular}

Berdasarkan tabel 4 rekapitulasi tanggapan pegawai untuk variabel prestasi kerja diketahui memiliki skor rata-rata 4,32 dengan kategori sangat setuju. Kemampuan dalam mengambil keputusan kerja yang sangat cermat memiliki skor tertinggi 4,50 dan terendah 4,16 mengenai kualitas tugas yang diselesaikan sudah sesuai standar yang ditetapkan perusahaan dan berusaha datang sebelum waktunya bekerja dimulai dan pulang sesudah waktu bekerja berakhir, serta meiliki loyalitas dan tanggungjawab terhadap pekerjaan.

Prestasi kerja mencerminkan keberhasilan atau kegagalan dalam aktivitas MSDM. Apabila prestasi kerja tidak sesuai dengan yang diharapkan perusahaan, maka memungkinkan aktivitas manajemen sumber daya manusia tersebut harus ditinjau ulang dengan melakukan penilaian terhadap prestasi kerja pegawai, (Husnan, 2002). Hal ini didukung oleh penelitian yang dilakukan Nancy Yusnita

(2014) yang mendapati pengaruh pelatihan terhadap prestasi kerja karyawan pada PT PDAM Tirta Pakuan.

Tabel 4. Rekapitulasi Tanggapan

Pegawai Untuk Variabel Pelatihan

\begin{tabular}{|c|c|c|c|}
\hline No & Pernyataan & $\begin{array}{c}\text { Penilaian } \\
\text { Pegawai }\end{array}$ & Keterangan \\
\hline 1 & $\begin{array}{l}\text { Menyelesaikan } \\
\text { tugas tepat } \\
\text { waktu }\end{array}$ & 4.36 & Sangat Baik \\
\hline 2 & $\begin{array}{l}\text { Memiliki } \\
\text { ketelitian yang } \\
\text { tinggi }\end{array}$ & 4.40 & Sangat Baik \\
\hline 3 & $\begin{array}{l}\text { Keterampilan } \\
\text { pegawai } \\
\text { mempercepat } \\
\text { penyelesaian } \\
\text { tugas }\end{array}$ & 4.26 & Sangat Baik \\
\hline 4 & $\begin{array}{l}\text { Kualitas tugas } \\
\text { sesuai dengan } \\
\text { standar }\end{array}$ & 4.16 & Baik \\
\hline 5 & $\begin{array}{l}\text { Selalu } \\
\text { mengerjakan } \\
\text { tugas secara } \\
\text { rutin }\end{array}$ & 4.36 & Sangat Baik \\
\hline 6 & $\begin{array}{l}\text { Mampu } \\
\text { mengambil } \\
\text { keputusan } \\
\text { secara cermat }\end{array}$ & 4.50 & Sangat Baik \\
\hline 7 & $\begin{array}{l}\text { Selalu } \\
\text { bersemangat } \\
\text { menyelesaikan } \\
\text { tugas }\end{array}$ & 4.43 & Sangat Baik \\
\hline 8 & $\begin{array}{l}\text { Berusaha datang } \\
\text { tepat waktu }\end{array}$ & 4.16 & Baik \\
\hline 9 & $\begin{array}{l}\text { Kerjasama } \\
\text { memudahkan } \\
\text { penyelesaian } \\
\text { pekerjaan }\end{array}$ & 4.26 & Sangat Baik \\
\hline & Total & 38.89 & \\
\hline & Rata-rata & 4.32 & Sangat Baik \\
\hline
\end{tabular}


Analisis regresi linier berganda digunakan untuk mengetahui variabel bebas terhadap variabel terikat. $\mathrm{Y}=3,290+$ $0,483 X_{1}+1,266 X_{2}+\varepsilon$.

Berdasarkan persamaan regresi tersebut diketahui bahwa :

1. $\beta_{1}=0,483$; Pendidikan berpengaruh positif terhadap prestasi kerja, bila pendidikan dilaksanakan dengan baik maka prestasi kerja juga akan meningkat.

2. $\beta_{2}=1,266$; Pelatihan berpengaruh positif terhadap prestasi kerja, bila pelatihan dilaksanakan dengan lebih baik maka prestasi kerja juga akan membaik.

\section{Pengujian Koefisien Determinasi $\left(\mathbf{r}^{2}\right)$}

Koefisien determinasi menunjukkan berapa besar presentase sumbangan pengaruh variabel independen pendidikan dan pelatihan terhadap variabel prestasi kerja secara simultan dapat dilihat dari $r$ square.

Berdasarkan hasil yang diperoleh diketahui $r$ square sebesar 0.863 atau 86,3 $\%$. Hal ini mengindikasikan bahwa presentase sumbangan pengaruh variabel pendidikan, pelatihan terhadap prestasi kerja sebesar 86,3\%. Sedangkan sisanya sebesar $13,7 \%$ dipengaruhi variabel lain seperti kepemimpinan, lingkungan kerja, disiplin kerja, dan motivasi kerja, (Sutrisno, 2011).

\section{Pengujian Hipotesis}

Berdasarkan nilai $\mathrm{F}$ pada Tabel 4.39, $F_{\text {hitung }} 84,812$ dan nilai $F_{\text {tabel }}$ untuk $\alpha=0,05$ dengan derajat kebebasan df1 $=3-1=2$ dan df2 $=30-3=27$ sebesar 3,35 di mana bisa dilihat bahwa $F_{\text {hitung }}>F_{\text {tabel }}(84,812>3,35)$ maka disimpulkan bahwa Ho ditolak dan Ha diterima artinya dengan tingkat kepercayaan $95 \%$ variabel independen yaitu pendidikan $\left(\mathrm{X}_{1}\right)$ dan pelatihan $\left(\mathrm{X}_{2}\right)$ secara bersama-sama mempunyai pengaruh positif dan signifikan terhadap prestasi kerja (Y). Adapun pengaruh secara parsial sebagai berikut :

\section{Pengaruh Pendidikan $\left(\mathrm{X}_{1}\right)$ Terhadap Prestasi Kerja (Y)}

Adapun cara statistik untuk dapat melihat ada atau tidaknya pengaruh pendidikan $\left(\mathrm{X}_{1}\right)$ terhadap prestasi kerja pegawi (Y), uji hipotesisnya sebagai berikut :

Ho : $\beta_{1} \leq 0$; variabel pendidikan tidak berpengaruh positif dan signifikan terhadap prestasi kerja.

Ha : $\beta_{1}>0$; variabel pendidikan berpengaruh positif dan signifikan terhadap prestasi kerja.

Berdasarkan Tabel 4.40 dapat dilihat bahwa $t_{\text {hitung }}$ pada variabel pendidikan $\left(\mathrm{X}_{1}\right)$ sebesar 2,926 dan nilai tabel untuk $\alpha=0,05$ dengan derajat kebebasan n-k-1 sama dengan $30-2-1=27$ sebesar 1,703 berarti $t_{\text {hitung }}>t_{\text {tabel }}(2,926>1,703)$, hal ini berarti Ha diterima dan Ho ditolak, artinya variabel pendidikan berpengaruh positif dan signifikan terhadap prestasi kerja.

\section{Pengaruh Pelatihan $\left(X_{2}\right)$ Terhadap Prestasi Kerja (Y)}

Adapun cara statistik untuk dapat melihat ada atau tidaknya pengaruh pelatihan $\left(\mathrm{X}_{2}\right)$ terhadap prestasi kerja pegawi (Y), uji hipotesisnya sebagai berikut:

Ho : $\beta_{1} \leq 0$; variabel pelatihan tidak berpengaruh positif dan signifikan terhadap prestasi kerja.

Ha : $\beta_{1}>0 \quad ;$ variabel pelatihan berpengaruh positif dan signifikan terhadap prestasi kerja.

Berdasarkan Tabel 4.40 tersebut dapat dilihat bahwa $t_{\text {hitung }}$ pada variabel pelatihan $\left(\mathrm{X}_{2}\right)$ sebesar 9,374 dan nilai $\mathrm{t}_{\text {tabel }}$ untuk $\alpha=$ 0,05 dengan derajat kebebasan n-k-1 sama dengan 30-2-1= 27 sebesar 1,703 berarti $t_{\text {hitung }}>t_{\text {tabel }}(9,374>1,703)$, hal ini berarti Ha diterima dan Ho ditolak, artinya 
variabel pendidikan berpengaruh positif dan signifikan terhadap prestasi kerja.

\section{KESIMPULAN DAN IMPLIKASI}

Berdasarkan hasil penelitian yang dilakukan, maka dapat disimpulkan bahwa pelaksanaan program pendidikan berlangsung dengan baik. Sedangkan pelaksanaan program pelatihan berlangsung dengan sangat baik. Prestasi kerja pada kantor Balitnak sangat baik. Hal ini ditunjukkan oleh penyelesaian tugas tepat waktu, ketelitian untuk mengurangi kesalahan, memiliki keterampilan, pekerjaan yang berkualitas, melakukan pekerjaan sesuai target, mampu mengambil keputusan, semangat tinggi dalam menyelesaikan tugas, loyalitas dan tanggungjawab dan mampu bekerja sama tim.

Program Pendidikan dan Pelatihan secara simultan berpengaruh positif dan signifikan terhadap prestasi kerja di Balai Penelitian Ternak. Program Pendidikan dan pelatihan secara parsial berpengaruh positif dan signifikan terhadap prestasi kerja di Balai Penelitian Ternak.

Berdasarkan pembahasan dan hasil penelitian, terdapat saran yang diberikan oleh penulis, diharapkan dapat bermanfaat bagi instansi yang terkait maupun bagi pihak-pihak lain, diantaranya 1. Pegawai perlu ditingkatkan pendidikannya, karena pendidikan pegawai di Balitnak masih belum optimal. 2. Untuk peneliti selanjutnya diharapkan agar dapat menambahkan variabel lain yang tidak diteliti dalam penelitian seperti kepemimpinan, lingkungan kerja, dan motivasi kerja. Hal ini bertujuan untuk memberikan pengaruh yang lebih besar lagi terhadap prestasi kerja.

\section{DAFTAR PUSTAKA}

Departemen Pendidikan Nasional, 2005. Kamus Besar Bahasa Indonesia, Balai Pustaka.Jakarta.

Faraditha. 2013.Pengaruh Program Training (Pelatihan) Terhadap Kualitas KaryawanPada Bagian Administrasi. PT. Sucofindo. Samarinda.

Hardjanto, Imam. 2012.Manajemen Sumber Daya Aparatur (MSDA. Malang.

Hasibuan, Malayu. 2006.Manajemen Sumber Daya Manusia. Edisi Revisi. PT. Bumi Aksara. Jakarta.

2005. Manajemen Sumber Daya Manusia dan Kunci Keberhasilan. PT. Bumi Aksara. Jakarta.

Heidjrachman dan Suad Husnan. 2007. Manajemen Personalia. Edisi 4. BPFE.Yogyakarta.

Husnan, Suad. 2007. Dasar-Dasar Teori pendidikan, Edisi Kedua. AMPYKPN.Yogyakarta.

Sumber Daya

Manusia.AMPYKPN. Yogyakart

a.

Mangkunegara, Anwar Prabu, 2001. Manajemen Sumber Daya Manusia Perusahaan. PT. Remaja Rosdakarya. Bandung.

Mangkuprawira, Sjafri. 2002. Manajemen Sumber Daya Manusia Strategik. Galia Indonesia. Jakarta.

Nitisemito, Alex. S. 2006. Manajemen Sumber Daya Manusia dan organisasi, Jakarta.

Notoatmodjo, 2003. Pengembangan Sumber Daya 
Manusia. PT. Rineka Cipta. Jakarta.
Peraturan Pemerintah No.101 Tahun 2000 Tentang pelatihan dan Pendidikan Pegawai Negeri Sipil. Permana, Yuliantini dan Bagia. 2016. Analisis Dampak Pelatihan Terhadap Prestasi Kerja Karyawan. Singaraja: E-journal Bisma Universitas pendidikan Ganesha.

Rivai, Veithzal dan Basri. 2011. Manajemen Sumber Daya Manusia. PT. Gravindo Persada.Jakarta.

Sugiyono, 2012.MetodePenelitian

Administrasi.

CV.

Alfabeta.Bandung. 2013. Statistika untuk penelitian. Cetakan ke-21. Alfabeta.Bandung.
Suharnomo dan Kambey. 2013.Pengaruh Pembinaan, Pelatihan Dan Pengembangan, Pemberdayaan Dan Partisipasi Terhadap Kinerja Karyawan. PT. Njonja Meneer.Semarang.

Sutrisno. 2011. Manajemen Sumber Daya Manusia. Prenada Group.Jakarta.

Uhbiyati Ahmadi dan. 2007. Ilmu Pendidikan. Rineka Cipta.Jakarta.

Undang-undang Republik Indonesia Nomor 20 Tahun 2003 tentang Sistem Pendidikan Nasional.

Undang-undang Nomor 13 Tahun 2003 tentang Ketenagakerjaan.

Undang-undang No.43 Tahun 1999 tentang Perubahan UndangUndang No.8 Tahun 1974 tentang pokok-pokok kepegawaian. 